\title{
UNDERUTILIZED MEDICINAL SPECIES OF CRAMBE L. OF THE FLORA OF UKRAINE
}

\author{
Kalista Mariia \\ National Museum of Natural History of NAS of Ukraine, Kyiv, Ukraine \\ Received 25. 6. 2017 \\ Revised 29. 6. 2017 \\ Published 27. 11. 2017
}

It was pointed out that 8 species of the genus Crambe L. are in the flora of Ukraine. All of them are subject of protection at the different levels, therefore they should be cultivated for their conservation. The species of the genus Crambe are mostly semirossette caudex perennial herbaceous polycarpic. Different representatives have inflorescences from 0.4 to $1.5-2.5 \mathrm{~m}$ length, which gives them a special decorative value. The chemical-biological features of these species show the necessity for their widespread introduction and cultivation in farming. They are promising for use in fodder, food, decorative and medicinal purposes. It was shown that cultivation of these species is easy and doesn't need many investments of money. These plants have a significant ability to grow after mowing. Low temperatures of germination of seeds are most important adaptations to the cool early spring period, which is good for growing under weather condition of Ukraine. Seeds of Crambe species keep their viability for 5 years or more. The norm of sowing is $5 \mathrm{~kg}$ of seeds per hectare. These species is adapted very well to the lack of moisture. Most species of Crambe were tested as forage plant, they shows easy process of cultivation and reach yields. Growing them for medicinal purpose (to extract vitamins and very important for human health substances) is very perspective for farming, because they content linoleic and linolenic acids, vitamin $\mathrm{C}$ and $\mathrm{B}_{1}$, carotene, and Crambe koktebelica has the antioxidant activity. Three species are cultivated in vitro and biochemical composition of their in vitro plants was found out and it showed significantly high content of important substances for medicine.

Keywords: Crambe L.; rare species; medicinal plant; seed germination; farming

\section{Introduction}

There are 8 species of the genus Crambe L. in the flora of Ukraine (Ільїнська та ін., 2007): Crambe aspera M. Bieb., Crambe grandiflora DC., Crambe koktebelica (Junge) N. Busch, Crambe maritima L., Crambe mitridatis Juz., Crambe pinnatifida W. T. Aiton, Crambe steveniana Rupr. and Crambe tataria Sebeòk. All of them are subject of protection at the state level, because they are listed in the Red Book of Ukraine (Червона книга..., 2009) as vulnerable species, and Crambe koktebelica as rare species. Such species as Crambe grandiflora and Crambe koktebelica are also protected by the International Union for Conservation of Nature and they have categories DD - Data Deficient (EU), NE- Not Evaluated (EU 27) (The IUCN Red List..., 2013). Three species have categories DD - Data Deficient (EU), NE - Not Evaluated (EU 27) (Crambe grandiflora, Crambe koktebelica, Crambe steveniana), two species have category LC - Least Concern (EU, EU 27) (Crambe maritima, Crambe tataria) and Crambe aspera has categories VU - Vulnerable (EU), NE - Not Evaluated (EU 27) in The European Red List (Bilz et

\footnotetext{
*Corresponding author: Mariia Kalista, National Museum of Natural History of NAS of Ukraine, Kyiv,
} Ukraine, $\triangle$ crambe@ukr.net 
al., 2011). It should be mentioned that there are not enough data to make an assessment of risk of extinction or it has not yet been evaluated against the criteria for majority of protected species. That's why these species need to be investigated in detail in natural habitats. It should also be noted that Crambe koktebelica and Crambe tataria are protected by the Bern Convention (Convention on..., 2013).

However, not only the high sozological status of all representatives of the genus Crambe of the flora of Ukraine indicates the need for their widespread introduction and cultivation, but also the chemicalbiological features of these species that make them promising for use in fodder, food, decorative and medicinal purposes (Калистая, 2016). This genus is one of important germplasms for vegetable production and industrial uses of its oil (Rudloff and Wan, 2011).

\section{Materials and methodology}

The literature data about chemical composition of 8 species (Crambe aspera, Crambe grandiflora, Crambe koktebelica, Crambe maritima, Crambe mitridatis, Crambe pinnatifida, Crambe steveniana and Crambe tataria ) of the genus Crambe in the flora of Ukraine are analysed for purpose of using them in farming as medicinal plants.

\section{Results and discussion}

Species of the genus Crambe are mostly semirossette caudex perennial herbaceous polycarpic (only Crambe koktebelica is mostly conodial perennial monocarpic) (Каліста та Щербакова, 2012a) with massive smooth (with bluish bloom) or with varying degrees of pubescence, which turn into the flowering phase at the age of 2-5 year. Different representatives have inflorescences from 0.4 to 1.5-2.5 m length, which gives them a special decorative value. Fruits are large single-seeded pods with varied surface structure. The root system is pivotal, about $5 \mathrm{~m}$ long with several massive lateral skeletal roots, due to which they adapt very well to the lack of moisture.

Crambe aspera has vitamin C and carotene in the aerial parts (Амирханов и др., 1974), as well as such flavonoids as glycosides of quartzetine and kaempferol. Seeds contain $25 \%$ fatty oil. Roots and young shoots (mature hard and strongly pubescent) of this species are used for edible purposes as a vegetable, and in boiled form as an asparagus. Also, the plant was tested as fodder and source of vitamins in Uzbekistan (Амирханов, 1974; Амирханов и др., 1978).

Crambe grandiflora is a vitamin, decorative, fodder, edible and anti-erosive species (Червона книга..., 2009), a purposeful study of its chemical properties, unfortunately, was not carried out, but it also has a very high potential for cultivation.

The leaves of Crambe koktebelica (incl. C. mitridatis) contains vitamin C and carotene (Амирханов и др., 1974), and their seeds have about $21 \%$ of fatty oil with oleic, erucic, linoleic, eicosinic, linolenic, palmitic, eicosalic, stearic, palmitolenic and myristic higher fatty acids (Доля и др, 1977). The species was tested as fodder in Uzbekistan (Амирханов и др., 1978) Also it shows antibacterial activity (Дикорастущие растения..., 2001), therefore it is promising for medicinal purposes (Каліста, 2013). It was also shown that aseptic cultivation of this species benefits to saturated fatty acid accumulation and increases protein content but on the other hand it reduces unsaturated fatty acid amount and polyfructan content as well as antioxidant activity of plant material. Obtained data confirms the prospect of biotechnology approach to biodiversity conservation and suggest the necessity of father in vitro cultivation effect on biochemical composition of plant (Pushkarova et al., 2016a). 
Crambe maritima contains such flavonoids as quercetin glycoside and kemiferol in the aerial parts and vitamin C, $B_{1}$ and carotene in the leaves (Амирханов и др., 1974), and its seeds contain $45 \%$ of fatty oil, which contains erucic, oleic, linoleic, arachine, linolenic, palmitic, eicosenic, stearic acids. Y Etiolated shoots of Crambe maritima is mainly used for food and leaves are eaten as salads, boiled shoots is used as asparagus (Растительные ресурсы..., 1985). Probably, this species was known even in ancient Rome, and from the XVII century and it began to be used as a delicious vegetable in England, France and the colonies of North America (Rudloff, Wan, 2011). This species is a honeycomb and an ornamental plant (Растительные ресурсы..., 1985). Crambe maritima was also tested as fodder in the arid zone of Uzbekistan (Амирханов и др., 1978).

Crambe pinnatifida contains erucic, oleic, linoleic, linolenic, eicosenic, lignoceric, docozaenoic, palmitic, eicosalic and myristic acids in the fatty oil of its seeds (Доля и др, 1977). Its shoots, leaves and roots are used for food (Дикорастущие растения..., 2001; Растительные ресурсы..., 1985).

Crambe steveniana has vitamin C in its roots (Растительные ресурсы..., 1985), and its seeds have about $19 \%$ of fatty oil containing erucic, linoleic, oleic, eicosenic, palmitic, lignoceric, docosadenoic, palmitolenic and myristic acids (Доля и др, 1977). Its roots are used for food as an acute seasoning (Растительные ресурсы..., 1985). It was also tested as a feed in Uzbekistan (Амирханов и др., 1978). The high $\alpha$-linolenic acid amount in the samples from in vitro grown plants was established. Significantly high erucic acid content was shown for seed samples (Пушкарьова та ін., 2016).

Crambe tataria contains vitamin C and carotene in its leaves (Амирханов и др., 1974), and seeds to have $43 \%$ fatty oils with oleic, linoleic, linolenic, eicosenoic, linoleic, palmitic, eicosadinoic, stearic, arachidic, palmitoleic and myristic acids (Доля и др, 1977). There is a lot of starch, sugars, many vitamins - ascorbic acid, thiamin, riboflavin, nicotinic acid, rutin, and mineral salts in the roots (Дудченко и др, 1989). Caudexes accumulates calcium (Дикорастущие растения..., 2001). Its roots have medicinal action as therapeutic general restorative (especially for children) (Растительные ресурсы..., 1985). According to their taste and nutritional qualities, the roots and caudexes approach the common horseradish (Armoracia rusticana P. Gaertn., B.Mey. \& Scherb.) and they are widely used in cooking in raw and canned form, in various sauces and salads (Циунель, 2008). The shoots and young leaves of Crambe tataria (matured is very hard and densely pubescent) are used as lettuce or asparagus (Растительные ресурсы..., 1985). Fat oil from its seeds is suitable for soap making, it is also used for food, despite the bitter taste, which resembles the taste of redhead oil. The plant has phytoncidal properties (Дудченко и др., 1989). Also, the species was tested as a forage plant in Uzbekistan (Амирханов и др., 1978) and it can be used as a feed for large and small cattle. Fat oil from seeds is suitable for soap making, it is also used for food, despite the bitter taste, which resembles the taste of redhead oil. The plant has phytoncidal properties (Dudchenko et al, 1989). Also, the species was tested as a forage plant in Uzbekistan (Amirkhanov et al, 1978) and it can be used as a feed for large and small cattle. Crambe tataria in vitro plants had high AOA and total soluble protein content along with high total FA content along with high content of $\alpha$-Linolenic acid and absence of erucic acid. (Pushkarova et al., 2016).

The seeds of representatives of the genus Crambe germinate only after a long stratification - the influence of low temperatures and moisture, which destroy its veils. Therefore, it is better to sow these plants in the autumn (the optimal period is the beginning of October and the end of November). Based on the results of our research (Каліста і Щербакова, 2012b), the stratification of seeds during the day at $0{ }^{\circ} \mathrm{C}$ provides $5 \%$ germination on the 41 st day, and when the seeds are soaked for 24 hours at $0{ }^{\circ} \mathrm{C}$, followed by removal of the seed coat $-95 \%$ germination on 5 day after embryo planting in 
Petri dishes. The rest of the seeds is due solely to the effect of the inhibitors of integuments (Коломиец и др., 1968), and not the embryo, therefore, when the veils are removed, the embryos germinate without cold stratification. Spermoderm, due to the presence of phenolic inhibitors, restricts the flow of water to the embryo, which in natural places of growth under conditions of insufficient moisture supply prevents the germination of seeds in the soil.

Most species of Crambe were tested as a forage plant in Uzbekistan, they shows easy process of cultivation and reach yields (Амирханов, 1974). Therefore cultivation them for medicinal purpose (to extract vitamins and very important for human health acids of fat oil) is very perspective for farming.

\section{Conclusions}

Representatives of the genus Crambe of the flora of Ukraine are very promising for vegetable growing, industrial use of oil, due to its relatively high content in seeds, as a very useful, vitamin-containing feed for livestock, and some species as a source of substances for medicinal purposes. All species are also especially ornamental plants. The chemical-biological features of these species show the necessity for their widespread introduction and cultivation in farming. They are promising for use in fodder, food, decorative and medicinal purposes. It was shown that cultivation of these species is easy and doesn't need many investments of money.

\section{Acknowledgments}

The publication was prepared with the active participation of researchers involved in the International network AgroBioNet of the Institutions and researchers for realization of research, education and development program «Agrobiodiversity for improving nutrition, health and life quality» and within the project ITMS 25110320104.

\section{References}

Bilz, M., Kell, S.P., Maxted, N., Lansdown, R.V. 2011. European Red List of Vascular Plants. Luxembourg. 130 p. Convention on the Conservation of European Wildlife and Natural Habitats. 2013. Access mode: http:// conventions.coe.int/Treaty/Commun/QueVoulezVous.asp?NT=104\&CM=8\&DF=06/08/2013\&CL=ENG

Pushkarova, N., Kalista, M., Kharkhota, M., Rakhmetov, D., Kuchuk, M. 2016b. Crambe tataria Sebeók seeds and plants grown in vitro and in vivo fatty acid composition comparison. Potravinarstvo, vol. 10, no. 1, p. 489-498. DOI: 10.5219/646.

Pushkarova, N.O., Kalista, M.S., Kharkhota M.A., Rakhmetov, D.B., Kuchuk, M.V. 2016a. Biotechnological approaches for conservation of the endangered species Crambe koktebelica (Junge) N. Busch and effect of aseptic in vitro cultivation on its biochemical properties. Biotechnologia Acta, vol. 9, no. 4, p. 19-27. https://doi.org/10.15407/biotech9.04.019

Rudloff, E., Wan, Y. 2011. Crambe. Wild Crop Relatives: Genomic and Breeding Resources. Oilseeds. Berlin. $295 \mathrm{p}$.

Амирханов, Н.А. 1974. Катран (Crambe (Tourn.) L.) в Узбекистане : автореф. диссертации. Ташкент : ТОТКЗГУ им. В.И. Ленина. 41 с.

Амирханов, Н.А., Мукумов, Х.Р., Хамракулов, Ш.С. 1974. Содержание витаминов и макроэлементов в некоторых видах Crambe L. Рaстительные ресурсы, т. 10, вып. 3, с. 422-426.

Амирханов, Н.А., Хамракулов, Ш.С., Мукумов, Х.Р. 1978. Некоторые итоги интродукции видов рода Катран в Узбекистане. Тезисы Всесоюзного совещания по технологии возделывания новых кормовых культур, ч. 2, с. 32-34.

Дикорастущие полезные растения России. 2001. Отв. ред. А.Л. Буданцев, Е.Е. Лесиовская. СанктПетербург. 663 с. 
Доля, В.С., Шкурупий, Е.Н., Каминский, Н.А., Магеря Е.Д. 1977. Масла семян девяти видов рода Crambe. Химия природних соединений, №1, с. 18-20.

Дудченко, Л.Г., Козьяков, А.С., Кривенко, В.В. 1989. Пряно-ароматические и пряно-вкусовые растения. Киев. 304 с.

Ільїнська, А.П., Дідух, Я.П., Бурда, Р.І., Коротченко, І.А. 2007. Екофлора України. Київ, т. 5.584 с.

Калистая, М.C. 2015. Перспективы культивирования некоторых представителей рода Crambe L. (Brassicaceae Burnett). Agrobiodivirsity for improving nutrition, health and life quality, Nitra, part 1, p. 318-321.

Каліста, М.С. 2013. Перспективи інтродукції та особливості культивування катрана коктебельського Crambe koktebelica (Junge) N. Busch (Brassicaceae Burnett). Нетрадиционные, новые и забытые виды растений: теоретические и практические аспекты культивирования. Київ : Книгоноша, с. $54-55$.

Каліста, М.С., Щербакова, О.Ф. 2012а. Біоморфогенез Crambe koktebelica (Junge) N. Busch в умовах Карадазького природного заповідника. Інтродукція рослин, № 4, с. 16-24.

Каліста, М.С., Щербакова, О.Ф. 2012b. Особливості насінневого розмноження та репродуктивна стратегія Crambe koktebelica (Junge) N. Busch. Bicmi Біосферного заповідника «Асканія Нова», т. 14, c. 440-447.

Коломиец, И.А., Парфенова, Т.М., Теплицкая, Е.В. 1968. Физиологические особенности покоя и прорастания семян катрана сердцелистного. Физиология растений, т. 15, № 6, с. 979-987.

Пушкарьова, Н.О., Каліста, М.С., Белокурова В.Б., Кучук М.В. 2016. Отримання культури рослин in vitro зникаючого виду Crambe steveniana та вивчення впливу асептичних умов культивування на їх біохімічний склад. Вісник Харківського начіонального університету імені В.Н.Каразіна. Series "Biology", № 27, с. 155-162.

Растительные ресурсы СССР.Цветковыерастения, иххимический состав, использование; Семейства Paeoniaceae - Thymelaeaceae. 1985. Отв. ред. П.Д. Соколов. Ленинград. 336 с.

Растительные ресурсы СССР. 1985. Цветковые растения, их химический состав, использование; Семейства Paeoniaceae - Thymelaeaceae. Отв. ред. П.Д. Соколов. Ленинград. 336 с.

Циунель, М. 2008. Заменитель хрена. Приусадебное хозяйство, №6, с. 40.

Червона книга України. Рослинний світ. 2009. Під заг.ред. Я.П. Дідуха. Київ. 900 с. 